\title{
THE EXPERIENCE OF IMPLEMENTATION OF THE COURSE DEVOTED TO THE FIELD- SPECIFIC SECTIONS OF HISTOLOGY, CYTOLOGY AND EMBRYOLOGY FOR THE STUDENTS OF THE FACULTY OF DENTISTRY IN ONMEDU
}

The experience of implementation of the course devoted to the field-specific sections of Histology, Cytology and Embryology for the students of the faculty of dentistry in ONMedU. The aim of the current article is to describe the course "Histology, Cytology and Embryology of the organs of the oral cavity", which was developed and firstly included in the working program for the students of the faculty of dentistry at the department of Histology, Cytology and Embryology of ONMedU. The article also presents the results of the assessment of the course effectiveness, which were determined by examination of the students' knowledge in the area of field-specific "dental" sections of the discipline before and after the implementation of the course. The results of the conducted research showed that the course "Histology, Cytology and Embryology of the organs of the oral cavity" was proved to be methodically effective, therefore the other higher medical education institutions of Ukraine could be recommended to include the course in working programs of the discipline "Histology, Cytology and Embryology" for the students of the faculty of dentistry.

Key words: Histology, Embryology, organs of the oral cavity.

The study of the histological features of the oral cavity and associated structures is an essential part of the professional training of the future dentists regardless of the specialization they are going to choose [9]. In Ukrainian higher medical education institutions the discipline "Histology, Cytology and Embryology" is studied by the students of the faculty of dentistry during first and second semesters of their first year of studying. Up to now, there was no specialized course focused on the study of the field-specific "dental" sections of the discipline "Histology, Cytology and Embryology" for the students of the faculty of dentistry. It is backed up the fact that number of hours devoted to studying of the topics "Oral cavity" and "The structure and eruption of teeth" is the same for the students of the faculty of dentistry and the faculty of the general medicine. That is why the staff of the department of Histology, Cytology and Embryology of Odessa National Medical University made a decision to develop the course "Histology, Cytology and Embryology of the organs of the oral cavity" and to introduce it into the working program of the discipline "Histology, Cytology and Embryology" for the students of the faculty of dentistry.

The aim of the current article is to describe the abovementioned course and to evaluate its necessity and effectiveness by analyzing the results of testing of the students who have undertaken and successfully completed the course.

The course "Histology and Embryology of the organs of the oral cavity" for the students of the faculty of dentistry was designed and developed at the department of Histology, Cytology and Embryology of Odessa National Medical University. The principal aim of this course is more detailed an in-depth study of professional sections of the discipline "Histology, Cytology and Embryology" by the students of the faculty of dentistry, and consequently the improvement of the professional training of the future dentists. The course lasts 24 academic hours including 16 hours devoted to practical classes $(8$ classes lasting 2 academic hours each), 4 hours devoted to lectures (2 classes lasting 2 academic hours each), and 4 academic hours given students for their individual work. The practical classes of the course totally cover the material regarding characteristic features of the histological structure and embryonic development of the oral cavity and associated structures and include the following themes:

Theme 1. Oral cavity. An overview of the structure of the oral cavity mucosa. Morphological and functional features of the particular areas of the oral cavity mucosa. Theme 2. Salivary glands; Theme 3 . An overview of the structure of teeth. Structure of dental enamel; Theme 4. Structure of dentin and cementum; Theme 5. Structure of pulp and supporting apparatus of teeth; Theme 6. Development and eruption of teeth -1 . Formation and differentiation of the tooth germs. Development of dentin and enamel; Theme 7. Development and eruption of teeth - 2. Development of dental pulp and periodonteum. Eruption of teeth; Theme 8. Embryonic development of the digestive system. Formation of face and oral cavity. The pattern of the practical classes implies discussion of the theoretical material, demonstration of visual materials and histological specimens and assessment of the student's work using traditional fivepoint academic grading scale. Besides this, the course program includes two lectures which are aimed at structuring and summarizing of the material studied during the practical classes. Accordingly, the themes of the lectures are: 1) Lecture 1. Organs of the oral cavity; 2) Lecture 2. Structure and development of teeth. The students' individual work, in its turn, implies that the students can choose the type of 
individual task they are going to complete. It might be conducting of scientific research or literature review on the given topic as wells as preparation of histological specimen or visual materials.

The staff of the department of Histology and Embryology started working on the course in 2012. In order to determine whether it is necessary to implement the course, it was decided to test the students of the faculty of dentistry who were studying at the department in that period and assess their awareness of professional sections of educational discipline "Histology and Embryology". In August 2014 the course "Histology, Cytology and Embryology of the organs of the oral cavity" was included in the working program of the educational discipline "Histology, Cytology and Embryology" for the students of the faculty of dentistry for 2014-2015 study year. The themes of the course started to be discussed in the section "Special histology and embryology of the organs of digestive system".

Material and methods. In accordance with the curriculum approved by the Ministry of Health of Ukraine, the educational discipline "Histology, Cytology and Embryology" lays the foundations of study of the propaedeutic of clinical disciplines, which means acquiring of knowledge in the area of histology, cytology and embryology and their implementing during further education and professional activity. It was this postulate which the staff of the department was guided by during designing of tasks aimed at assessment of the competency of the students of the faculty of dentistry in the area of oral histology, cytology and embryology. In order to design the tasks which will be focused on only the aspects of the oral histology, cytology and embryology that are significant in practical dentistry it was conducted the analysis of textbooks of therapeutic, prosthetic, surgical and pediatric dentistry such as: 1) "Therapeutic dentistry. Volume 1. Phantom course", Kyiv, 2007 (Danylevskyi M.F., Borysenko A.V., Politun A.M., Sidelnikova L.F., Nesyn, O.F.) [1]; 2) "Therapeutic dentistry. Volume 3. Disesases of periodonteum", Kyiv, 2008 (Danylevskyi M.F., Borysenko A.V. et all.) [2]; 3) "Therapeutic dentistry. Volume 4. Diseases of the oral cavity mucosa", Kyiv, 2013 (Danylevskyi M.F., Borysenko A.V., Antonenko M. Yu.) [3]; 4) "Maxillofacial surgery", Kyiv, 2010 (Timofeiev A.A.) [8]; 5) "Therapeutic pediatric dentistry", Kyiv, 2007 (edited by Khomenko, L.A.) [6]; 6) "Orthodontics", Kyiv, 2008 (Flis P.S.) [4]; 7) "Prosthetic dentistry", Kyiv, 2003 (Rozhko M.M., Nespriadko V.P.) [7]; 8) "Surgical dentistry and maxillofacial surgery in children", Kyiv, 2005 (Kharkov, L.V., Yakovenko, L.N., Chekhova I.L.) [5].

The specially designed for the testing question sheets had an appearance of a table whose right column contained questions, whereas the left column contained spaces for answers. The questions demanded quite simple answers, which should have consisted of no more than 1-3 words. Some questions required to give more than one answers (list several items). In this case the number of lines against the question corresponded to the number of correct answers, which helped students to a certain degree. The students were given 1 point for each correct answer. The maximal score gained for these tasks was 28 points. Besides the abovementioned, in the first task of the test the students were asked to give definition to a term. For this task they might gain from 0 to 4 points, depending on the extent to which the meaning of the term was explained. The first task was included in the test in order to assess the ability of students to express their thoughts regarding professional topic and operate with scientific terms. Therefore, the maximal overall score in this test was 32 points. The sample of test question sheet is given below.

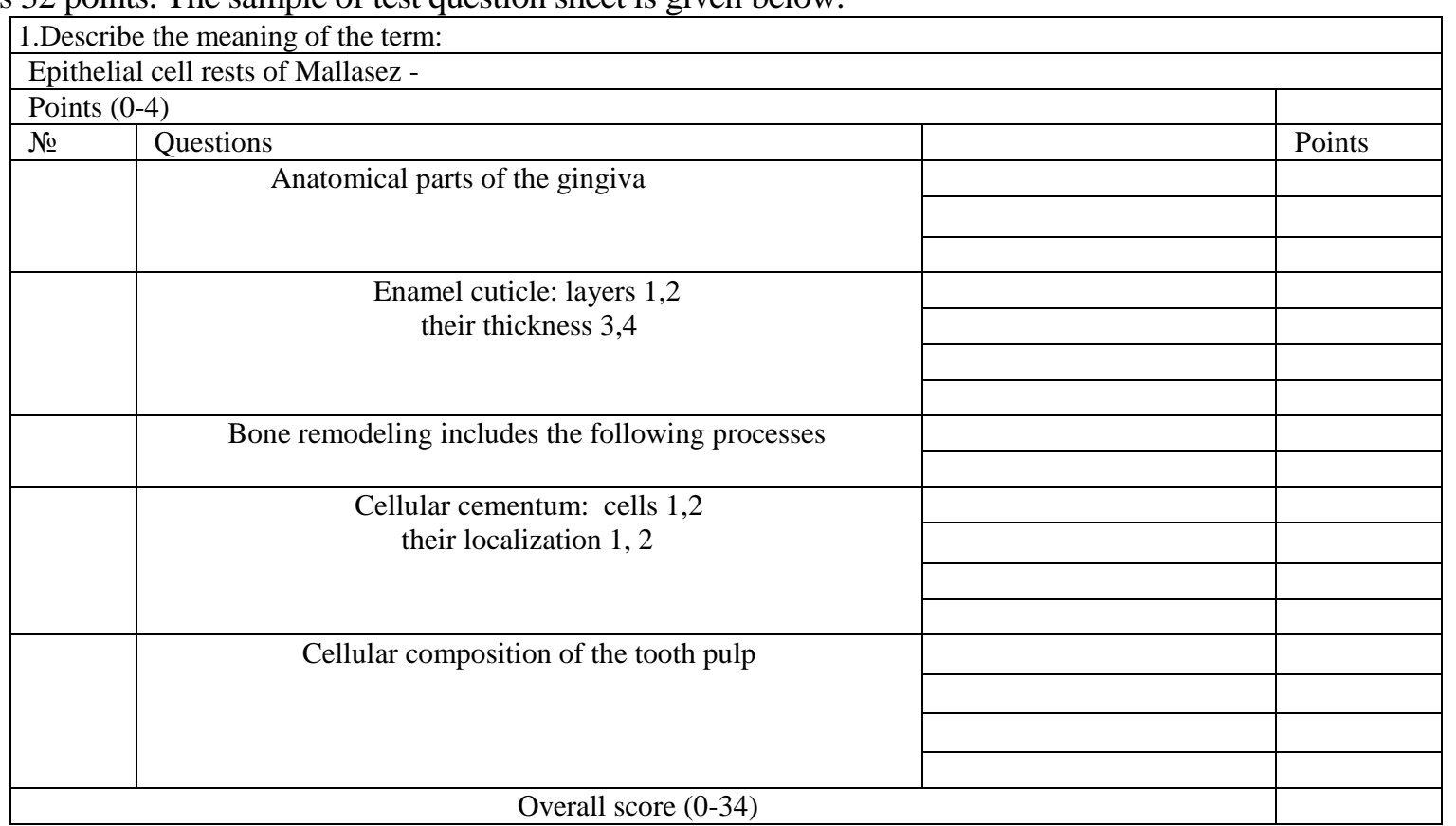


The tests were checked and marked by an expert committee which consisted of professor, docents and senior lecturers of the department of Histology, Cytology and Embryology of Odessa National Medical University. Taking into consideration that, according to working programs of the discipline "Histology, Cytology and Embryology" for 2012-2013 years, the number of academic hours devoted to study of the oral histology, cytology and embryology was the same for the students of the faculty of dentistry and for the students of the faculty of general medicine it was decided to test the students of the both faculties. Thereby the students of the faculty of general medicine were considered to be a control group. The test was taken by the students of the faculty of dentistry and the students of the faculty of general medicine in three different years $(2013,2015$ and 2017). The results were compared and illustrated in the column chart 1 . It was considered that the students successfully passed the test if they gained at least $60 \%$ of the maximal overall score (at least 19 points out of 32). It should be mentioned that only the students who did not have met all the course requirements were eligible for the test, which makes the results of statistical analysis more valid.

Results and discussion. In May 2013 the test was taken by 200 students of the faculty of dentistry and 200 students of the faculty of general medicine. In the column chart 1 . it is observed that in 2013, before implementation of the course "Histology, Cytology and Embryology of the organs of the oral cavity", only $15 \%$ of the students of the faculty of general medicine and $12 \%$ of students of the faculty of dentistry passed the test of knowledge in the field of oral histology, cytology and embryology.

In the end of 2014-2015 study year the students of the faculty of general medicine and the students of the faculty of dentistry, who had already successfully completed the course "Histology, Cytology and Embryology of the organs of the oral cavity", taken the test analogous to that proposed to the students in May 2013.

The column chart 1. illustrates that in 2015, after the including of the course "Histology, Cytology and Embryology of the organs of the oral cavity" in the working program for the students of the faculty of dentistry, $60 \%$ of students of the faculty dentistry passed the test of knowledge of the professional aspects of oral histology and embryology, whereas such percentage of the students of the faculty of general medicine did not exceed $14 \%$.

Due to the obtained results it was made an ultimate decision to include the course "Histology, Cytology and Embryology of the organs of the oral cavity" in the working program of the discipline "Histology, Cytology and Embryology" for the students of the faculty of dentistry in Odessa National Medical University. In May 2017 the control examination of the students of the faculty of dentistry and the faculty of the general medicine was carried out.

The results are shown in the column chart 1 . In 2017 the percentage of the students of the faculty of dentistry who had passed the test accounted for $72 \%$. In contrast, such percentage constituted only $18 \%$ among students of the faculty of dentistry.

\section{Conclusion}

Having taken all the abovementioned into consideration, the staff of department of Histology, Cytology and Embryology of Odessa National Medical University came to conclusion that the course "Histology, Cytology and Embryology of the organs of the oral cavity" was proved to be highly effective and therefore the other higher medical education institutions of Ukraine could be recommended to include the course in working programs of the discipline "Histology, Cytology and Embryology" for the students of the faculty of dentistry.

\section{References}

1. Danylevskyi M.F. Terapevtychna stomatologia - T.1. Fantomnyi kurs / M. F. Danylevskyi, A. V. Borysenko, A. V. Politun ta in. // - 2e vyd. - Kyiv: Medicina, - 2007. - 303 p.

2. Danylevskyi M.F. Terapevtychna stomatologia - T.3. Zahvoriuvannia parodonta / M. F. Danylevskyi, A. V. Borysenko [et al.] // - Kyiv: Medicina, - 2008. - 616 p.

3. Danylevskyi M.F. Terapevtychna stomatologia - T.4. Zahvoriuvannia slyzovoi obolonky porozhnyny rota / M.F. Danylevskyi, A.V. Borysenko, M.Yu. Antonenko // - Kyiv: Medicina, - 2013. - 632 p.

4. Flis P.S. Ortodontiia / P.S. Flis // - Kyiv: Medicina, - 2008. - 360 p.

5. Kharkov L.V. Khirurgicheskaia stomatologiia i cheliustno-litsevaia khirurgiia detskogo vozrasta / L.V. Kharkov, L.N. Yakovenko, I.L. Chekhova // - Kyiv: Kniga Plius, - 2005. - 488 p.

6. Khomenko L.A. Terapevticheskaia stomatologia detskogo vozrasta / L.A. Khomenko // - Kyiv: Kniga Plius, - 2007.816 p.

7. Rozhko M.M. Ortopedychna stomatologia / M.M. Rozhko, V.P. Nespriadko// - Kyiv: Kniga Plius, - 2003. - 552 p.

8. Timofeiev A.A. Cheliustno-litsevaia khirurgiia / A. A. Timofeiev // - Kyiv: VSI Medicina, - 2010. - 576 p.

9. Yui R. I. Teaching of field-specific sections in histology at KAZNMU dentistry faculty / R.I. Yui, M. Zh. Ergazina, Zh. O. Ayapova // Vestnik KAZNMU - 2014. - No. 3 (2). - P. 178-18.

Наши статьи 
Pepepari

ОПЫТ ВНЕДРЕНИЯ КУРСА, ПОСВЯЩЕННОГО ИЗУЧЕНИЮ ПРОФИЛЬНЫХ РАЗДЕЛОВ

ГИСТОЛОГИИ, ЦИТОЛОГИИ И ЭМБРИОЛОГИИ ДЛЯ СТУДЕНТОВ СТОМАТОЛОГИЧЕСКОГО ФАКУЛЬТЕТА В ОНМЕДУ

Талалаев К. А., Тирон О. И., Кувшинова И. И., Тодорова A. B.

Целью данной статьи является описание курса «Гистология, цитология и эмбриология органов ротовой полости», который был разработан и впервые внедрен в рабочую программу для студентов стоматологического факультета на кафедре гистологии, цитологии и эмбриологии ОНМедУ. Также в статье приведены результаты оценки эффективности вышеуказанного курса, которая определялась путем анализа результатов тестирования знаний студентов в области профильных «стоматологических» разделов дисциплины до и после внедрения курса. Результаты проведенного исследования показали, что курс «Гистология, цитология и эмбриология органов ротовой полости» является методически эффективным и может быть рекомендован для включения в рабочие программы для стоматологического факультета другим медицинским ВУЗам Украины.

Ключевые слова: гистология, эмбриология, органы ротовой полости.

Стаття надійшла 3.08.2017 p.

\section{ДОСВІД ВПРОВАДЖЕННЯ КУРСУ, ЩО \\ ПРИСВЯЧЕНИЙ ПРОФІЛЬНИМ РОЗДІЛАМ \\ ГІСТОЛОГІї, ЦИТОЛОГІї ТА ЕМБРІОЛОГІї ДЛЯ \\ СТУДЕНТІВ СТОМАТОЛОГІЧНОГО \\ ФАКУЛЬТЕТУ В ОНМЕДУ \\ Талалаев К. А., Тірон О. І., Кувшинова І. І., Тодорова}

A. B.

Метою даної статті $є$ описання курсу «Гістологія, цитологія та ембріологія органів ротової порожнини», який був розроблений та вперше включений до робочої програми для студентів стоматологічного факультету на кафедрі гістології, цитології та ембріології ОНМедУ. Також у статті наведені результати оцінки ефективності вищевказаного курсу, яка визначалася шляхом тестування знань студентів у галузі профільних «стоматологічних» розділів дисципліни до та після впровадження курсу. Результати проведеного дослідження показали, що курс «Гістологія, цитологія та ембріологія органів ротової порожнини» $є$ методично ефективним та може бути рекомендований для впровадження в робочі програми для стоматологічного факультету іншим ВНЗ медичної освіти України.

Ключові слова: гістологія, ембріологія, органи ротової порожнини.

DOI 10.26724 / 2079-8334-2017-4-62-219-224

УДК 347.788.4

В. О.Ульянов, Г.О.Ульянва

Одеський національний медичий університет, м. Одеса, Національний університет «Одеська юридична академія», м. Одеса

\section{АКАДЕМІЧНИЙ ПЛАГІАТ У МЕДИЧНИХ ДОСЛІДЖЕННЯХ}

e-mail: ulianova@onua.edu.ua

У статті досліджуються доктринальні і законодавчий підходи до визначення категорії «плагіат». В результаті плагіату не тільки витрачаються фінансові та часові ресурси на неналежні дослідження, також підвищується недовіра до медичних досліджень, у тому числі виникає можливість застосування до пацієнтів неефективних методів лікування. Академічний плагіат $є$ серйозним порушенням прав інтелектуальної власності, в результаті якого може бути завдано майнову та немайнову шкоду правоволодільцям. Істотною відмінністю між науковим і законодавчим підходом до визначення категорії «плагіат» є визнання плагіатом привласнення авторства на ідею. Відповідно до закону ідея не захищається як об'єкт авторського права. Тому академічний плагіат - це привласнення авторства на наукову роботу, наукове відкриття. Разом з тим ідея також $є$ результатом інтелектуальної діяльності. Тому важливо знайти механізми іiі захисту від неправомірного використання. Академічний плагіат - системна проблема, тому результативним може бути тільки комплексний підхід до ії вирішення.

Ключові слова: плагіат в медичних дослідженнях, незаконне привласнення авторства, академічний плагіат, ідея, опублікування твору.

Відповідно до ст. 54 Конституції України держава сприяє розвиткові науки, встановленню наукових зв'язків України зі світовим співтовариством.

Однією 3 найбільш актуальних сфер наукових досліджень, від результативності та ефективності яких залежить забезпечення життя та здоров'я людей, є медична. Складність досліджень у медичній галузі обумовлена необхідністю проведення численних дослідів, спостережень, випробувань нових ліків, методів діагностування та лікування, що вимагає суттєвих не лише часових, а й фінансових витрат. У зв'язку з чим особливої актуальності набуває питання захисту прав інтелектуальної власності творців, забезпечення академічної доброчесності при проведенні медичних досліджень, захисту від поширення псевдонаукових результатів та плагіату. Негативні наслідки від академічного плагіату у наукових дослідженнях полягають у: порушенні прав та інтересів винахідників, авторів; погіршенні якості наукових досліджень, відсутності нових наукових досягнень; зниженні якості навчальних матеріалів, що може впливати і на якість підготовки майбутніх фахівців; негативному впливі на репутацію наукового закладу, в 